\title{
Selective isolation and eradication of E. coli associated with urinary tract infections using anti-fimbrial modified magnetic reduced graphene oxide nanoheaters
}

Authors: Fatima Halouane ${ }^{\mathrm{ab}}$, Roxana Jijie ${ }^{\mathrm{a}}$, Dalila Meziane ${ }^{\mathrm{b}}$, Chengnan $\mathrm{Li}^{\mathrm{a}}$, Santosh K. Singh $^{\mathrm{c}}$, Julie Bouckaert ${ }^{\mathrm{d}}$, Jean Jurazek ${ }^{\mathrm{e}}$, Sreekumar Kurungot ${ }^{\mathrm{cf}}$, Alexandre Barras ${ }^{\mathrm{a}}$, Musen $\mathrm{Li}^{\mathrm{g}}$, Rabah Boukherroub ${ }^{\mathrm{a}}$ and Sabine Szunerits*a

${ }^{a}$ Univ. Lille, CNRS, Centrale Lille, ISEN, Univ. Valenciennes, UMR 8520-IEMN, F-59000

Lille, France. E-mail: sabine.szunerits@ univ-lille1.fr

${ }^{\mathrm{b}}$ Département de Chimie, Faculté des Sciences, Université Mouloud Mammeri, B. P N_17

RP, 15000 Tizi Ouzou, Algeria

${ }^{\mathrm{c}}$ Physical and Materials Chemistry Division, CSIR-National Chemical Laboratory, Dr Homi

Bhabha Road, Pune 411008, India

${ }^{\mathrm{d}}$ Unité de Glycobiologie Structurale et Fonctionnelle (UGSF), UMR 8576 of the CNRS and the Univ. Lille, 50 Av. de Halley, 59658 Villeneuve d'Ascq, France

${ }^{\mathrm{e}}$ Laboratoire Groupe de Physique des Matériaux (GPM), UMR6634 CNRS-Université de

Rouen-INSA de Rouen, Avenue de l'Université BP12, F-76801 Saint Etienne du Rouvray cedex, France

${ }^{\mathrm{f}}$ Academy of Scientific and Innovative Research, Anusandhan Bhawan, 2 RafiMarg, New

Delhi 110 001, India

${ }^{\mathrm{g}}$ Key Laboratory for Liquid-Solid Structural Evolution and Processing of Materials (Ministry of Education), Shandong University, Jinan 250061, China

First published: 01/09/2017

DOI: $10.1039 / \mathrm{C} 7 \mathrm{~TB} 01890 \mathrm{H}$

Abstract.

The fast and efficient elimination of pathogenic bacteria from water, food or biological samples such as blood remains a challenging task. Magnetic isolation of bacteria from complex media holds particular promise for water disinfection and other biotechnological applications employing bacteria. When it comes to infectious diseases such as urinary tract infections, the selective removal of the pathogenic species in complex media such as human serum is also of importance. This issue can only be accomplished by adding pathogen specific targeting sites onto the magnetic nanostructures. In this work, we investigate the potential of 2-nitrodopamine modified magnetic particles anchored on reduced graphene oxide (rGO) nanocomposites for rapid capture and efficient elimination of E. coli associated with urinary tract infections (UTIs) from water and serum samples. An optimized magnetic nanocarrier achieves a $99.9 \%$ capture efficiency even at E. coli concentrations of $1 \times 10^{1} \mathrm{cfu} \mathrm{mL}^{-1}$ in 30 min. In addition, functionalization of the nanostructures with poly(ethylene glycol) modified pyrene units and anti-fimbrial E. coli antibodies allowed specific elimination of E. coli UTI89 from serum samples. Irradiation of the E. coli loaded nanocomposite with a near-infrared laser results in the total ablation of the captured pathogens. This method can be flexibly modified

DOI: $10.1039 / \mathrm{C} 7 \mathrm{~TB} 01890 \mathrm{H}$ - Journal: Journal of Materials Chemistry B : Materials for biology and medicine - Post-print 
for any other pathogenic bacteria, depending on the antibodies used, and might be an interesting alternative material for a magnetic-based body fluid purification approach.

\section{Introduction}

Elimination of bacteria from water, food or in clinical settings is still a challenging task. The strategies for bacteria isolation and/or ablation from solutions are currently based on the removal of bacteria via membranes and filters using size discrimination approaches ${ }^{1,2}$ as well as nanostructure based systems, which allow the removal of bacteria from solutions through interaction with the particle surface as well as the ablation of pathogens due to the intrinsic antibacterial properties of these nanostructures. ${ }^{3-8}$ This last system requires strong, efficient and selective binding of the pathogen to the nanostructures. In this regard, magnetic separation techniques based on magnetic nanostructures allow for easy removal of bacteria from different media via a contactless and harmless external magnet. ${ }^{4-6,8-16}$ In addition to the magnetic properties, the high surface/volume ratio of magnetic particles offers more contact surface area for binding pathogen ligands and subsequent capture of pathogens. The size of these particles is typically 2 orders of magnitude smaller than a bacterium, which permits the attachment of multiple particles onto a bacterial cell making magnetic-mediated separation much easier. The removal efficiency of bacteria using magnetic nanoparticles remains however rather low. These systems are also not highly effective in removing ultralow bacteria concentrations $\left(<1 \times 10^{2} \mathrm{cfu} \mathrm{mL}^{-1}\right)$ due to unspecific interactions with other molecules and substances present next to bacteria, limiting their practical applications. More advanced particle systems, easily separated from water, that exhibit limited nonspecific interactions and are target specific with high loading capacity at high and low bacteria concentrations would be a great advantage.

In this work, we demonstrate that some of the mentioned limitations of magnetic nanoparticles can be overcome through hybridization of nitrodopamine coated magnetic particles $\left(\mathrm{MP}_{\mathrm{ND}}\right)$ onto anti-fouling reduced graphene oxide ( $\left.\mathrm{rGO}\right)$ nanosheets (Fig. 1). This novel magnetic nanocomposite material combines several features: (a) a $\mathrm{rGO} / \mathrm{MP}_{\mathrm{ND}}$ based matrix offering large surface area for effective binding of bacteria, (b) good magnetic properties for the removal of bacteria, (c) decreased non-specific interaction with serum proteins due to the presence of poly(ethylene glycol) functionalized pyrene units (pyrenePEG), (d) target-specificity towards type-1 fimbriae carrying E. coli such as uropathogenic ones due to the integration of anti-fimbrial E. coli antibodies, and (d) photothermal properties which allow the eliminated pathogens to be ablated on the matrix.

DOI: $10.1039 / \mathrm{C} 7 \mathrm{~TB} 01890 \mathrm{H}$ - Journal: Journal of Materials Chemistry B : Materials for biology and medicine - Post-print 

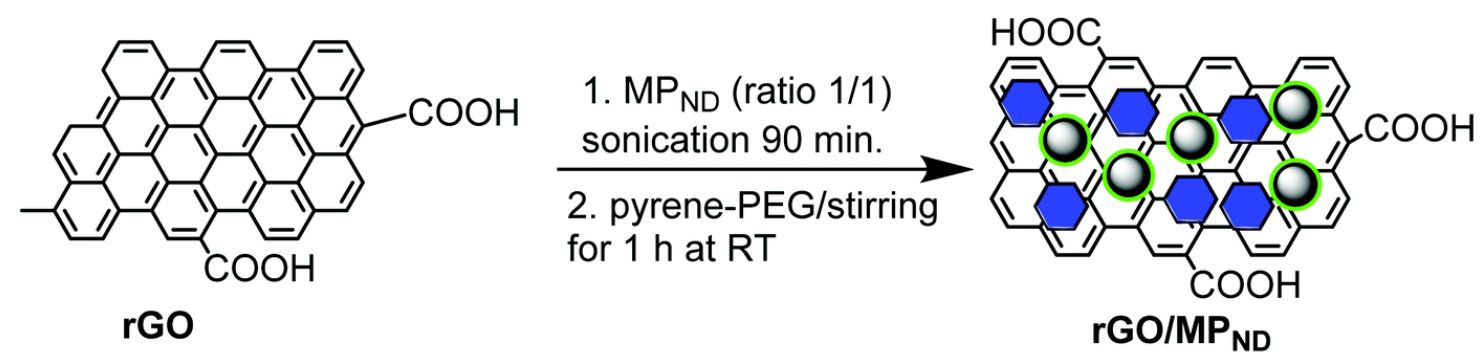

$$
\text { (NO }
$$

2-nitrodopamine (ND)<smiles>C#CCOCCOCCOCCNC(=O)CCc1ccc2ccc3cccc4ccc1c2c34</smiles>

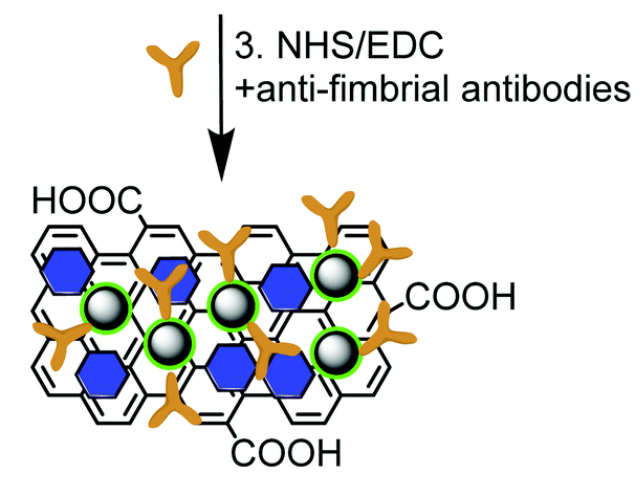

1. selective removal of E. coli UTI89

2. high elimination capacitance even in serum

3. photothermal pathogens ablation on magnetic matrix

Fig. 1 Schematic illustration of the fabrication of magnetic nanoheaters for pathogen isolation together with their different advantages.

\section{Experimental}

\subsection{Materials}

Hydrazine monohydrate, chitosan, dopamine hydrochloride, sodium nitrite $\left(\mathrm{NaNO}_{2}\right)$, sulfuric acid $\left(\mathrm{H}_{2} \mathrm{SO}_{4}\right)$, hydrochloric acid $(\mathrm{HCl})$, dichloromethane $\left(\mathrm{CH}_{2} \mathrm{Cl}_{2}\right)$, iron(II) chloride tetrahydrate $\left(\mathrm{FeCl}_{2} \cdot 4 \mathrm{H}_{2} \mathrm{O}\right)$, iron(III) chloride hexahydrate $\left(\mathrm{FeCl}_{3} \cdot 6 \mathrm{H}_{2} \mathrm{O}\right)$, ammonium hydroxide $\left(\mathrm{NH}_{4} \mathrm{OH}\right)$, O-(2-aminoethyl)-O'-(2-methylethyl)heptaethylene glycol $\left(\geq 90 \%, \mathrm{NH}_{2^{-}}\right.$ $\left.\mathrm{PEG}_{8}-\mathrm{N}_{3}\right)$, dichloromethane $\left(\geq 99.8 \%, \mathrm{CH}_{2} \mathrm{Cl}_{2}\right), \mathrm{N}, \mathrm{N}^{\prime}$-disuccinimidyl carbonate $(\geq 95.0 \%$, DSC), 1-pyrenecarboxylic acid (97\%, Pyr-COOH) and triethylamine ( $\geq 99.5 \%$, TEA) were obtained from Sigma-Aldrich. Milli-Q water (18 M $\Omega$ ) was used for all experiments. All reagents and solvents were used without further purification.

Graphene oxide (GO) powder was purchased from Graphenea, Spain.

Serum samples were kindly provided by the CHU, Lille.

Anti-fimbrial antibodies were obtained by immunizing serum from rats with purified fimbriae, which were delipidated and purified on an HiFliQ ProteinA affinity chromatography column (CliniSciences) and eluted at $1 \mathrm{mg} \mathrm{mL}^{-1}$ concentration in sodium citrate buffer at $\mathrm{pH}$ 5.6 .

DOI: $10.1039 / \mathrm{C} 7 \mathrm{~TB} 01890 \mathrm{H}$ - Journal: Journal of Materials Chemistry B : Materials for biology and medicine - Post-print 
Three kinds of bacteria were used: the Gram-negative wild type E. coli UTI89 (UTI89 WT) and an E. coli UTI89 strain lacking type-1 fimbriae (UTI89 $\Delta$ fim), and the Gram-positive Staphylococcus aureus.

Synthesis of 2-nitrodopamine. 2-Nitrodopamine was synthesized according to ref. 17. Dopamine hydrochloride $(1.90 \mathrm{~g}, 10 \mathrm{mmol})$ and sodium nitrite $(1.52 \mathrm{~g}, 22 \mathrm{mmol})$ were dissolved in water $(25 \mathrm{~mL})$ and cooled to $0{ }^{\circ} \mathrm{C}$. Sulfuric acid $(17.4 \mathrm{mmol}$ in $10 \mathrm{~mL}$ of water) was added slowly to the mixture, and a yellow precipitate was formed. After stirring at room temperature overnight, the precipitate was filtered and recrystallized from water to give the product as a hemisulfate salt. Yield $1.9 \mathrm{~g}(77 \%)$. ${ }^{1} \mathrm{H}$ NMR (DMSO- $\left.\mathrm{d}_{6}, 300 \mathrm{MHz}, \mathrm{ppm}\right): 3.10$ (br s, 4H, $\mathrm{CH}_{2} \mathrm{CH}_{2}$ ), 6.85 (s, 1H), $7.47(\mathrm{~s}, 1 \mathrm{H})$.

Synthesis of N-(26-azido-3,6,9,12,15,18,21,24-octaoxahexacosyl)pyrene-1-carboxamide (pyrene-PEG). Pyrene-PEG was synthesized as reported earlier by our group. $\frac{18}{}$ Briefly, 1 pyrenecarboxylic acid $(100 \mathrm{mg}, 0.41 \mathrm{mmol})$ and DSC (125 mg, $0.49 \mathrm{mmol})$ were dissolved in anhydrous $\mathrm{CH}_{2} \mathrm{Cl}_{2}(15 \mathrm{~mL})$. To this solution, TEA $(68 \mu \mathrm{L}, 0.49 \mathrm{mmol})$ and $\mathrm{NH}_{2}-\mathrm{PEG}_{8}-\mathrm{N}_{3}(214$ $\mathrm{mg}, 0.49 \mathrm{mmol})$ dissolved in $\mathrm{CH}_{2} \mathrm{Cl}_{2}(2 \mathrm{~mL})$ were slowly added under stirring. The resulting mixture was kept under stirring overnight at room temperature. Then the solvent was evaporated under vacuum. The crude product was dissolved in $\mathrm{CH}_{2} \mathrm{Cl}_{2}(6 \mathrm{~mL})$, washed with $5 \% \mathrm{HCl}$ aqueous solution ( $5 \mathrm{~mL}$, twice) and $\mathrm{H}_{2} \mathrm{O}\left(5 \mathrm{~mL}\right.$, twice), and dried over $\mathrm{MgSO}_{4}$. The residue was purified by silica gel column chromatography using $\mathrm{CH}_{2} \mathrm{Cl}_{2}$ and the product was isolated as a viscous pale yellow oil; yield $=135 \mathrm{mg}, 50 \% ;{ }^{1} \mathrm{H} \mathrm{NMR}\left(300 \mathrm{MHz}, \mathrm{CDCl}_{3}\right) \delta$ $8.63(\mathrm{~d}, 1 \mathrm{H}, \mathrm{J}=9 \mathrm{~Hz}, \mathrm{py}), 8.3-8.0(\mathrm{~m}, 8 \mathrm{H}, \mathrm{py}), 7.06$ (bt, 1H, J = 4.3 Hz, $-\mathrm{NH}-)$, 3.9-3.3 (m, $36 \mathrm{H}, \mathrm{PEG}) ;{ }^{13} \mathrm{C}$ NMR $\left(75 \mathrm{MHz}, \mathrm{CDCl}_{3}\right) \delta 128.6,127.2,126.3,125.8,125.7,124.9,124.7$, 124.5, 124.4, 70.8-69.6, 50.7, 40.1; FT-IR: 717, 763, 820, 852, 948, 1039, 1104, 1181, 1248, $1289,1328,1348,1455,1532,1602,1648,2104,2867 \mathrm{~cm}^{-1}$.

\subsection{Preparation of 2-nitrodopamine modified magnetic particles (MPND)}

Magnetic particles (MP) were prepared as reported previously. ${ }^{19} \mathrm{FeCl}_{2} \cdot 4 \mathrm{H}_{2} \mathrm{O}(0.34 \mathrm{~g}, 1.7$ $\mathrm{mmol})$ and $\mathrm{FeCl}_{3} \cdot 6 \mathrm{H}_{2} \mathrm{O}(0.95 \mathrm{~g}, 3.5 \mathrm{mmol})$ were dissolved in deaerated water $(20 \mathrm{~mL})$ and subsequently added to a nitrogen-protected three-necked flask under sonication. The resulting mixture was heated at $50{ }^{\circ} \mathrm{C}$ for $30 \mathrm{~min}$. Then concentrated ammonium hydroxide $(2 \mathrm{~mL})$ was added dropwise and kept at $50{ }^{\circ} \mathrm{C}$ for $30 \mathrm{~min}$. The system was finally cooled to room temperature and the solid product was isolated via a non-uniform magnetic field generated by a Nd-Fe-B permanent magnet. The resulting $\mathrm{Fe}_{3} \mathrm{O}_{4}$ particles (MPs) were washed six times with Milli-Q water to remove unreacted chemicals and then stored in water.

A water dispersion of bare MPs (10 $\mathrm{mg} \mathrm{mL}^{-1}, 1 \mathrm{~mL}$ ) was mixed with 2-nitrodopamine (20 $\mathrm{mg}$ ) and sonicated for $1 \mathrm{~h}$ at room temperature. The formed magnetic particles $\left(\mathrm{MP}_{\mathrm{ND}}\right)$ were isolated by means of a magnet and purified through six consecutive wash/precipitation cycles with water to ensure complete removal of unreacted dopamine. The precipitate was dried in an oven at $50{ }^{\circ} \mathrm{C}$.

DOI: $10.1039 / \mathrm{C} 7 \mathrm{~TB} 01890 \mathrm{H}$ - Journal: Journal of Materials Chemistry B : Materials for biology and medicine - Post-print 


\subsection{Integration of MPND onto reduced graphene oxide (rGO)}

Reduced graphene oxide (rGO) was prepared from GO precursor using hydrazine reduction. Briefly, to $5 \mathrm{~mL}$ of $\mathrm{GO}$ aqueous suspension $\left(0.5 \mathrm{mg} \mathrm{mL}^{-1}\right)$ was added hydrazine hydrate $(0.50$ $\mathrm{mL}, 32.1 \mathrm{mM}$ ) and heated in an oil bath at $100{ }^{\circ} \mathrm{C}$ for $24 \mathrm{~h}$ over which the reduced GO gradually precipitated out of the solution. The product was isolated by filtration over a PVDF membrane with a $0.45 \mu \mathrm{m}$ pore size, washed copiously with water $(5 \times 20 \mathrm{~mL})$ and methanol $(5 \times 20 \mathrm{~mL})$ and dried in an oven at $100{ }^{\circ} \mathrm{C}$ overnight.

To a solution of $\mathrm{rGO}\left(0.5 \mathrm{mg} \mathrm{mL} \mathrm{L}^{-1}\right)$ was added an aqueous solution of $\mathrm{MP}_{\mathrm{ND}}\left(0.5 \mathrm{mg} \mathrm{mL}^{-1}\right)$ corresponding to a ratio of $1 / 1$ and sonicated for $90 \mathrm{~min}$. The formed $\mathrm{rGO} / \mathrm{MP}_{\mathrm{ND}}$ nanostructures were isolated by means of a magnet and purified through six consecutive wash/precipitation cycles with water. The precipitate was dried in an oven at $50{ }^{\circ} \mathrm{C}$.

\subsection{Functionalization of rGO/MPND with pyrene-PEG}

The $\mathrm{rGO} / \mathrm{MP}_{\mathrm{ND}}$ nanostructures $\left(500 \mu \mathrm{g} \mathrm{mL}^{-1}\right)$ were mixed with pyrene-PEG solution $(5 \mathrm{mM})$ and the suspensions were stirred for $1 \mathrm{~h}$ at room temperature. All samples were isolated by means of a magnet and purified through six consecutive wash/precipitation cycles with water.

\subsection{Covalent linking of anti-fimbrial antibody onto pyrene-PEG-rGO/MPND}

Anti-fimbrial antibody immobilization onto $\mathrm{rGO}-\mathrm{MP}_{\mathrm{ND}}$ nanostructures was achieved by carbodiimide crosslinking chemistry. Briefly, the $\mathrm{rGO} / \mathrm{MP}_{\mathrm{ND}}$ nanocomposite $\left(500 \mu \mathrm{g} \mathrm{mL}^{-1}\right)$ was mixed with a 100 times diluted antibody solution of $1 \mathrm{mg} \mathrm{mL}^{-1}$ in PBS at $\mathrm{pH}=7.4$ containing $\mathrm{EDC} \cdot \mathrm{HCl}(25 \mathrm{mM})$ and NHS $(25 \mathrm{mM})$. The reaction was left to proceed at $4{ }^{\circ} \mathrm{C}$ for $2 \mathrm{~h}$ under agitation, followed by magnetic extraction and PBS washing to remove weakly adsorbed antibodies. The particles were stored in PBS buffer at $4{ }^{\circ} \mathrm{C}$ before use.

\subsection{Quantification of amino groups by a modified Kaiser test}

Primary amine groups were quantified using a modified photometric assay. $\frac{20}{}$ Briefly, the $\mathrm{MP}_{\mathrm{ND}}$ particles $\left(500 \mu \mathrm{g} \mathrm{mL}^{-1}\right)$ were dissolved in $1 \mathrm{~mL}$ of Milli-Q water. To this suspension was added $1 \mathrm{~mL}$ of the buffer solution ( $36 \mathrm{~g}$ of sodium acetate were dissolved in $6.9 \mathrm{~mL}$ of acetic acid and filled with Milli-Q water up to a volume of $100 \mathrm{~mL}$ ) and then sonicated for 15 min. After that, $1 \mathrm{~mL}$ of $\mathrm{KCN}$ solution $(2 \mathrm{~mL}$ of $0.03 \mathrm{M} \mathrm{KCN}$ solution was diluted to a volume of $100 \mathrm{~mL}$ with pyridine) and $1 \mathrm{~mL}$ of phenol solution ( $80 \mathrm{~g}$ of phenol were dissolved in $20 \mathrm{~mL}$ of ethanol) were added and the suspension was heated at $120{ }^{\circ} \mathrm{C}$ for $10 \mathrm{~min} ; 1 \mathrm{~mL}$ of ninhydrin solution ( $5 \mathrm{~g}$ of ninhydrin was dissolved in $100 \mathrm{~mL}$ of ethanol) was added and heated for another $10 \mathrm{~min}$. After the solution was cooled to room temperature, $5 \mathrm{~mL}$ of ethanol was added (60\%) and the absorbance was recorded at $570 \mathrm{~nm}$.

\subsection{Instrumentation}

NMR spectra were recorded with a Bruker Advance $300 \mathrm{MHz}$ spectrometer using deuterated chloroform as the lock and TMS as an internal standard.

DOI: $10.1039 / \mathrm{C} 7 \mathrm{~TB} 01890 \mathrm{H}$ - Journal: Journal of Materials Chemistry B : Materials for biology and medicine - Post-print 
Thin layer chromatography (TLC) was carried out using pre-coated aluminium backed silica TLC plates (Alugram ${ }^{\circledR}$ SIL G/UV ${ }_{254}$, Macherey-Nagel) which were visualized using ultraviolet light. Column chromatography was performed on Sigma-Aldrich® silica gel 60 (pore size $60 \AA, 230-400$ mesh particle size) without applied pressure.

Reversed phase - high performance liquid chromatography (RP-HPLC) analyses were realized on a Shimadzu LC2010-HT (Shimadzu, Tokyo, Japan). A $5 \mu \mathrm{m}$ C4 QS Uptisphere ${ }^{\circledR}$ $300 \AA, 250 \times 4.6 \mathrm{~mm}$ column (Interchim, Montluçon, France) was used as the analytical column. The column was heated to $40{ }^{\circ} \mathrm{C}$. The mobile phase was a mixture of eluent $\mathrm{A}$ (trifluoroacetic acid $0.05 \%$ in $\mathrm{H}_{2} \mathrm{O}$ ) and eluent $\mathrm{B}$ (trifluoroacetic acid $0.05 \%$ in $\mathrm{CH}_{3} \mathrm{CN}$ ) at a flow rate of $1 \mathrm{~mL} \mathrm{~min}{ }^{-1}$. The linear gradient was 0 to $80 \%$ of eluent $\mathrm{B}$ in $30 \mathrm{~min}$ and the detection was performed at 215 and $254 \mathrm{~nm}$ after the injection of $40 \mu \mathrm{L}$ into the column.

High resolution transmission electron microscopy (HR-TEM) analysis of the prepared samples was carried out by using an FEI, TECNAI G2 F20 instrument operated at an accelerated voltage of $300 \mathrm{kV}\left(\mathrm{C}_{\mathrm{s}}=0.6 \mathrm{~mm}\right.$, resolution $\left.1.7 \AA\right)$. For the TEM analysis, the sample was prepared by drop casting $10 \mu \mathrm{L}$ of the dispersed solution of $1 \mathrm{mg}$ of material in 5 $\mathrm{mL}$ of isopropyl alcohol over a carbon coated 200 mesh $\mathrm{Cu}$ grid. The catalyst drop cast $\mathrm{Cu}$ grid was dried and the prepared sample was used for imaging purposes.

Absorption spectra were recorded using a Perkin Elmer Lambda UV-Vis 950 spectrophotometer in a $1 \mathrm{~cm}$ quartz cuvette. The wavelength range was 200-1200 nm.

Fourier transform infrared (FTIR) spectra were recorded using a ThermoScientific FTIR instrument (Nicolet 8700) at a resolution of $4 \mathrm{~cm}^{-1}$. Dried samples $(1 \mathrm{mg})$ were mixed with $\mathrm{KBr}$ powder $(100 \mathrm{mg})$ in an agate mortar. The mixture was pressed into a pellet under 10 tons load for 2-4 min, and the spectrum was recorded immediately. Sixteen accumulative scans were collected. The signal from a pure $\mathrm{KBr}$ pellet was subtracted as the background.

Zeta-potential measurements were performed using a zeta-sizer nano-ZS (Malvern Instruments Inc. Worcestershire, UK). The samples were diluted to $10 \mu \mathrm{g} \mathrm{mL} \mathrm{m}^{-1}$ and measured in Milli-Q water at different $\mathrm{pH}$ values.

$\mathrm{N}_{2}$ adsorption-desorption data were obtained using a Quantachrom SI Micromeritics apparatus, and the isotherms were evaluated with the Barrett-Joyner-Halenda method to determine the surface area, pore size and distribution.

Magnetic properties were determined using an MPMS-XL SQUID magnetometer. The magnetization loops $\mathrm{M}(\mathrm{H})$ were measured at $300 \mathrm{~K}$ by sweeping the applied magnetic field between $20 \mathrm{kOe}$ and $-20 \mathrm{kOe}$. Thermal variation of magnetization was measured using the zero-field-cooled (ZFC) procedure, for which the sample is first cooled down to $5 \mathrm{~K}$ in the absence of an applied magnetic field, and then magnetization is measured during the warming of the sample up to $400 \mathrm{~K}$, with an applied magnetic field of $80 \mathrm{Oe}$.

\subsection{Measurement of the photothermal effect}

All irradiations were performed in standard 24 well plates. A $980 \mathrm{~nm}$ continuous wave laser (Gbox model, Fournier Medical Solution, France) was used for the photothermal experiments. 6

DOI: $10.1039 / \mathrm{C} 7 \mathrm{~TB} 01890 \mathrm{H}$ - Journal: Journal of Materials Chemistry B : Materials for biology and medicine - Post-print 
This laser was injected into a $400 \mu \mathrm{m}$ core fiber and placed around $3 \mathrm{~cm}$ away from the bottom of the wells. The reported laser power densities take this distance into account. The temperature changes were captured using an infrared camera (Thermovision A40) and treated using ThermaCam Researcher Pro 2.9 software.

\subsection{Bacterial growth conditions}

E. coli UTI89 wild-type strain, UTI $89 \Delta$ fim (without fim operon) and S. aureus cultures were grown on an LB agar plate upon inoculation overnight in Luria-Bertani (LB) broth at $37^{\circ} \mathrm{C}$ with moderate shaking $(200 \mathrm{rpm})$. Upon 50 -fold dilution, incubation was prolonged until the $\mathrm{OD}_{600}$ had reached 0.5 equivalent to $1 \times 10^{9}$ cells $\mathrm{mL}^{-1}(\mathrm{cfu})$. The bacteria were re-suspended in PBS $(10 \mathrm{mM})$ and adjusted to the required concentration.

\subsection{Bacteria isolation}

The bacterial suspensions were diluted to the desired concentration $\left(1 \times 10^{1}\right.$ to $1 \times 10^{8} \mathrm{cfu}$ $\left.\mathrm{mL}^{-1}\right)$. Magnetic nanostructures of different concentrations $\left(4-10 \mathrm{mg} \mathrm{mL}^{-1}\right.$ ) were dispersed via ultrasonication (5 min, ultrasonic bath Branson 5800) in PBS (5 mL, $10 \mathrm{mM}, \mathrm{pH} 7.4$ ). Bacterial suspensions $(5 \mathrm{~mL})$ were mixed with the magnetic nanostructures $(5 \mathrm{~mL})$ under shaking $\left(200 \mathrm{rpm}, 37^{\circ} \mathrm{C}\right)$. After a given time interval, an aliquot was taken periodically to measure the remaining bacterial cell concentration by UV/Vis in solution after magnetic nanostructures had been separated by applying an external magnetic field.

The collection efficiency (E) was calculated according to:

$$
E(\%)=\frac{\left(A_{0}-A_{\mathrm{t}}\right)}{A_{0}} \times 100
$$

where $\mathrm{A}_{0}$ is the initial $\mathrm{OD}_{600}$ and $\mathrm{A}_{\mathrm{t}}$ the $\mathrm{OD}_{600}$ after cell capture. The capacity $(\mathrm{Q}$, cells per $\mathrm{mg}$ ) was calculated according to:

$$
Q(\text { cells per mg })=\frac{\left(A_{0}-A_{\mathrm{t}}\right) \times[\text { E.coli }]}{0.1 \times c}
$$

where $\mathrm{c}$ is the concentration of the particles $\left(\mathrm{mg} \mathrm{mL}^{-1}\right)$ and [E. coli] is the concentration of the pathogen in solution.

\subsection{Photothermal treatment of magnetically separated pathogens}

The magnetic nanostructures used for the separation of the pathogens were irradiated with a $980 \mathrm{~nm}$ continuous wave laser (Gbox model, Fournier Medical Solution, France) for $10 \mathrm{~min}$ at $1 \mathrm{~W} \mathrm{~cm}^{-2}$ and cell viability assessed by counting the viable bacterial colonies.

\subsection{Bacterial cell viability}

Following magnetic separation as well as photothermal treatment of the nanostructures, the presence and survival of bacteria were assessed by determining the titer of viable bacteria able 7

DOI: $10.1039 / \mathrm{C} 7 \mathrm{~TB} 01890 \mathrm{H}$ - Journal: Journal of Materials Chemistry B : Materials for biology and medicine - Post-print 
to grow. A 10-fold dilution series of the bacterial solutions in phosphate buffered saline were spotted in $10 \mu \mathrm{L}$ aliquots on an LB-agar medium. Visual counting of the number of colonies upon overnight incubation at $37^{\circ} \mathrm{C}$ allowed the initial and final concentrations of the E. coli strain in cfu $\mathrm{mL}^{-1}$ to be determined.

\subsection{Fluorescence-based cell dead/live assay}

The separated bacteria were immediately stained for cell viability assays. The total amount of live and dead bacteria cells was determined using the live/dead BacLight bacterial viability

staining kit (Invitrogen). A 1 : 1 mixture of SYTO 9 nucleic acid stain and propidium iodide (PI) was prepared and $3 \mu \mathrm{L}$ were added to the separation matrix, mixed thoroughly and incubated at room temperature in the dark for $15 \mathrm{~min} .5 \mu \mathrm{L}$ of the stained bacteria suspension was deposited between a glass slide and a cover slip. The slides were observed using a Leica AF6000 LX fluorescent microscope equipped with an Andor iXon 885 Camera and by using an oil immersion objective (100x; 1.4 NA objective). The fluorescence signal was acquired using dual band excitation and emission filter sets for green fluorescent protein (GFP) and red fluorescent protein (mCherry).

\section{Results and discussion}

\subsection{Fabrication of magnetic reduced graphene oxide nanosheets}

Our approach is based on the pre-synthesis of magnetic nanoparticles, and their integration into reduced graphene oxide ( $\mathrm{rGO}$ ) nanosheets, followed by functionalization with pyrenePEG as well as E. coli UTI 89 specific anti-fimbrial antibodies (Fig. 1) to obtain magnetic nanostructures with high and selective bacterial elimination efficiency, which can be used in aqueous solution as well as in more complex media such as serum.

We have shown previously that 2-nitrodopamine is an excellent ligand to stabilize iron oxide particles formed using the co-precipitation reaction of $\mathrm{Fe}^{2+}$ and $\mathrm{Fe}^{3+}$ in alkaline media. ${ }^{19}$ This amine-terminated ligand is indeed known to be a far superior ligand to stabilize magnetic particles than dopamine. $\stackrel{21-23}{2}$ The higher oxidation potential of the 2-nitrodopamine ligand implies that nanoparticle surface degradation is diminished, ensuring irreversible binding of the ligands and good stability of the resulting nanostructures. These properties are crucial when using such particles for follow-up reactions and in biomedical applications. $\underline{24}$ Furthermore, $\pi-\pi$ stacking interaction of the catechol groups with the aromatic network of a rGO might be in addition favorable for the formation of stable nanostructures.

The 2-nitrodopamine coated iron oxide particles were characterized by FTIR (Fig. 2A) and Xray photoelectron spectroscopy (XPS) (Fig. 2B). The FTIR spectrum of the $\mathrm{MP}_{\mathrm{ND}}$ particles exhibits a band at $\approx 1290 \mathrm{~cm}^{-1}$ corresponding to $\mathrm{C}-\mathrm{O}$ or $\mathrm{NO}_{2}$ vibration. The band at $1500 \mathrm{~cm}^{-1}$

is due to the $\mathrm{C} \quad \mathrm{C}$ vibration of the catechol system, which overlaps with the asymmetric vibrations of $\mathrm{NO}_{2}$ at about $1548 \mathrm{~cm}^{-1}$. The bands at 2882 and $2920 \mathrm{~cm}^{-1}$ are due to $\mathrm{CH}$ stretching vibrations of the dopamine ligand. The broad band at $3367 \mathrm{~cm}^{-1}$ and the band at $1650 \mathrm{~cm}^{-1}$ are ascribed to the stretching and bending mode of primary amines, respectively. The content of nitrogen in the $\mathrm{MP}_{\mathrm{ND}}$ particles determined by XPS was 3.3 at $\%$, indicating 8

DOI: $10.1039 / \mathrm{C} 7 \mathrm{~TB} 01890 \mathrm{H}$ - Journal: Journal of Materials Chemistry B : Materials for biology and medicine - Post-print 
further that 2-nitrodopamine is bonded to the surface of the magnetic particles. The amino group density was in addition determined using the UV spectroscopic method proposed by Kaiser et al..$\underline{20}$ and proposed by Krueger for the analysis of nanoparticles. $\frac{25}{\text { The amount of }}$ primary amino groups on the $\mathrm{MP}_{\mathrm{ND}}$ particles was found to be $45 \pm 11 \mathrm{nM} \mathrm{g}^{-1}$, in accordance with other amino-functionalized magnetic particles. $\underline{\underline{26}}$

(A)

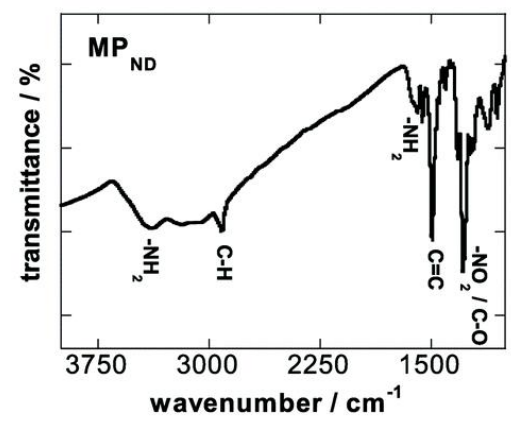

(B)

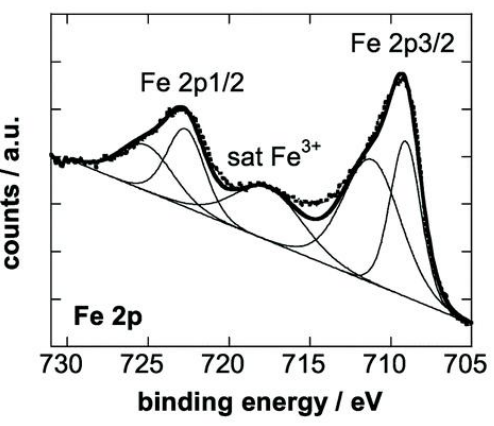

(C)
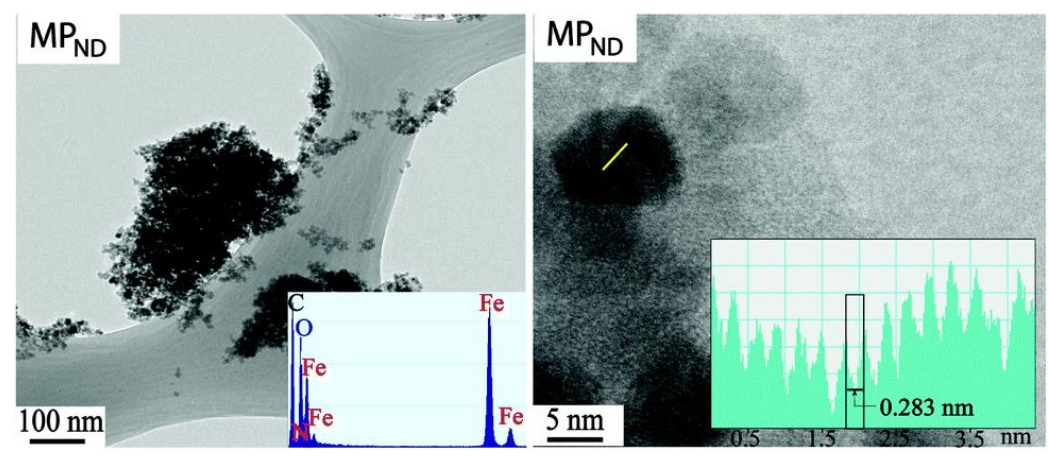

Fig. 2 Characterization of $\mathrm{MP}_{\mathrm{ND}}$ : (A) FTIR spectrum; (B) $\mathrm{Fe}_{2 \mathrm{p}}$ high resolution XPS spectrum; (C) transmission electron microscopy (TEM) and HRTEM analysis (inset: EDAX analysis displaying the different elements present in the sample).

A representative $\mathrm{Fe}_{2 \mathrm{p}}$ core level XPS spectrum is seen in Fig. 2B. The $\mathrm{Fe}_{2 \mathrm{p} 3 / 2}$ region can be deconvoluted into bands at 709.01 and $711.02 \mathrm{eV}$, indicating the presence of both $\mathrm{Fe}^{2+}$ and $\mathrm{Fe}^{3+}$ species. The satellite peak at $\approx 717 \mathrm{eV}$ is a direct evidence for the presence of $\mathrm{Fe}^{3+}$ in the form of $\gamma-\mathrm{Fe}_{2} \mathrm{O}_{3}$, suggesting that the 2-nitrodopamine coated magnetic particles are partially oxidized.

To get more insight into the structure and morphology of the $\mathrm{MP}_{\mathrm{ND}}$, transmission electron microscopy (TEM) analysis was performed by imaging a sample coated $\mathrm{Cu}$ grid (Fig. 2C). The size of the nanoparticles is in the range of 8-10 nm. EDAX analysis displays different elements $(\mathrm{Fe}, \mathrm{O}, \mathrm{C}, \mathrm{N})$ present in the sample in accordance with the chemical structure of the particles. Furthermore, high resolution transmission electron microscopy (HRTEM) analysis was performed to get more information about the sample. The HRTEM image of $\mathrm{MP}_{\mathrm{ND}}$ displays fringes with a calculated fringe width of $0.283 \mathrm{~nm}$ corresponding to the iron oxide nanoparticles. Dynamic light scattering measurements were performed in addition to

DOI: $10.1039 / \mathrm{C} 7 \mathrm{~TB} 01890 \mathrm{H}$ - Journal: Journal of Materials Chemistry B : Materials for biology and medicine - Post-print 
determine the hydrodynamic diameter of the particles, which was determined to be $140 \pm 50$ nm.

The $\mathrm{MP}_{\mathrm{ND}}$ particles were incorporated into reduced graphene oxide (rGO) by mixing a $1: 1$ ratio and sonicating for $2 \mathrm{~h}$. The FTIR spectra of rGO before and after loading with $\mathrm{MP}_{\mathrm{ND}}$ particles are displayed in Fig. 3A. The spectrum of rGO is dominated by a band at $\sim 1570$ $\mathrm{cm}^{-1}$ due to a $\mathrm{C}=\mathrm{C}$ stretching mode of the aromatic rings. The presence of an $\mathrm{O}-\mathrm{H}$ stretching vibration band $\left(\sim 3430 \mathrm{~cm}^{-1}\right)$ and stretching modes due to other oxygen containing groups implies the incomplete removal of oxygen groups as expected for rGO. The bands at 1734 and $1094 \mathrm{~cm}^{-1}$ correspond to $\mathrm{C}=\mathrm{O}$ stretching vibration of residual $-\mathrm{COOH}$ and $\mathrm{C}-\mathrm{O}$ functions, respectively. Loading of $\mathrm{rGO}$ with $\mathrm{MP}_{\mathrm{ND}}$ particles results in a comparable FTIR spectrum as for $\mathrm{rGO}$ with additional bands at $2882 \mathrm{~cm}^{-1}\left(\mathrm{C}-\mathrm{H}\right.$ stretching) and $1233 \mathrm{~cm}^{-1}$ due to symmetric vibrations of $\mathrm{NO}_{2}$ groups.

(A)

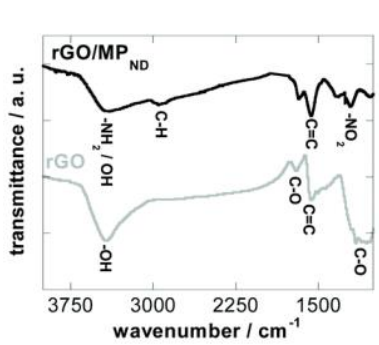

(C)

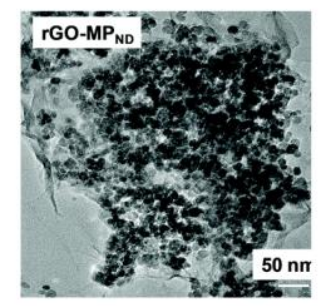

(E)
(B)

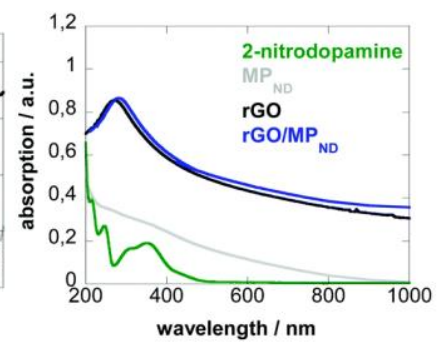

(D)

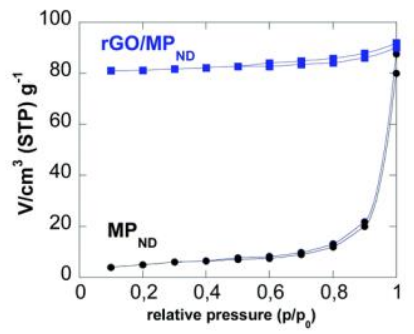

(F)
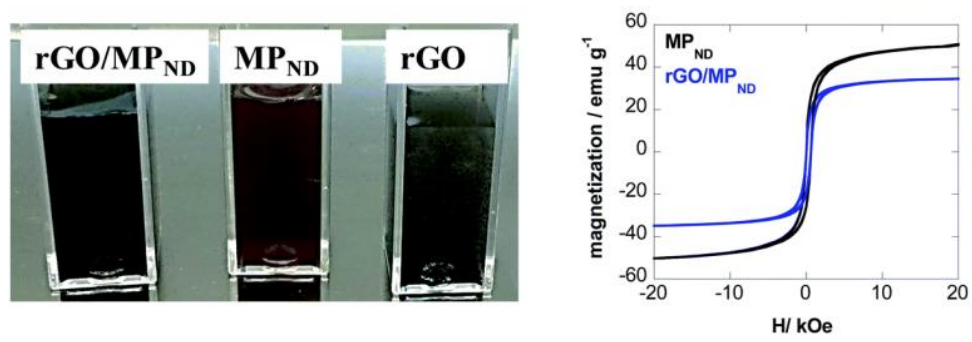

Fig. 3 Characterization of $\mathrm{rGO} / \mathrm{MP}_{\mathrm{ND}}$ particles: (A) FTIR spectra of $\mathrm{rGO}$ (grey) and $\mathrm{rGO} / \mathrm{MP}_{\mathrm{ND}}$ (black); (B) UV/Vis absorption spectra of $\mathrm{MP}_{\mathrm{ND}}$ (grey), rGO (black) and $\mathrm{rGO} / \mathrm{MP}_{\mathrm{ND}}$ (blue); (C) TEM image of $\mathrm{rGO} / \mathrm{MP}_{\mathrm{ND}}$; (D) $\mathrm{N}_{2}$ adsorption-desorption isotherms for $\mathrm{MP}_{\mathrm{ND}}$ (black) and $\mathrm{rGO} / \mathrm{MP}_{\mathrm{ND}}$ (blue); (E) photographs of aqueous dispersions of $\mathrm{rGO}, \mathrm{MP}_{\mathrm{ND}}$ and $\mathrm{rGO} / \mathrm{MP}_{\mathrm{ND}}\left(500 \mu \mathrm{g} \mathrm{mL}^{-1}\right) ;(\mathrm{F})$ hysteresis curves of $\mathrm{MP}_{\mathrm{ND}}$ and $\mathrm{rGO} / \mathrm{MP}_{\mathrm{ND}}$.

DOI: $10.1039 / \mathrm{C} 7 \mathrm{~TB} 01890 \mathrm{H}$ - Journal: Journal of Materials Chemistry B : Materials for biology and medicine - Post-print 
The UV-vis spectrum of hydrazine reduced GO (Fig. 3B) displays an optical absorption peak at $273 \mathrm{~nm}$ with an absorption tail in the NIR characteristic of rGO. The UV-vis spectrum of the free 2-nitrodopamine ligand exhibits a prominent peak at $352 \mathrm{~nm}$. The UV-vis spectrum of $\mathrm{rGO} / \mathrm{MP}_{\mathrm{NP}}$ nanostructures is comparable to that of $\mathrm{rGO}$ and exhibits a broad absorption maximum at $273 \mathrm{~nm}$ and an absorption tail until the NIR.

TEM imaging of the $\mathrm{rGO} / \mathrm{MP}_{\mathrm{ND}}$ hybrid reveals the integration of $\mathrm{MP}_{\mathrm{ND}}$ nanostructures onto the rGO nanosheets (Fig. 3C) with the overall size of the hybrid estimated to be $200 \pm 60 \mathrm{~nm}$.

The surface area of the $\mathrm{rGO} / \mathrm{MP}_{\mathrm{ND}}$ hybrid was determined from $\mathrm{N}_{2}$ adsorption-desorption isotherms as shown in Fig. 3D. The $\mathrm{N}_{2}$ adsorption-curve of $\mathrm{MP}_{\mathrm{ND}}$ can be classified as typical type II without a hysteresis loop. ${ }^{27}$ In the case of $\mathrm{rGO} / \mathrm{MP} \mathrm{ND}_{\mathrm{ND}}$, the curve is close to type IV with a weak hysteresis loop in the 0.4-1.0 relative pressure range with the specific surface area increased to $81.71 \mathrm{~m}^{2} \mathrm{~g}^{-1}$. This increased active surface area will be favorable for the efficient removal of pathogens, as confirmed in the following experiments.

Fig. 3E indicates the difference in colloidal stability of a $\mathrm{rGO} / \mathrm{MP}_{\mathrm{ND}}$ hybrid in water compared to rGO. While $\mathrm{MP}_{\mathrm{ND}}$ particles have good colloidal stability, from the photographs in Fig. 3E it is evident that the stability of aqueous suspensions of $\mathrm{rGO}$ is poor. The $\mathrm{rGO}$ particles have completely settled on the bottom of the cuvette after $24 \mathrm{~h}$. In the case of the $\mathrm{rGO} / \mathrm{MP}_{\mathrm{ND}}$ hybrid the slightly opaque color indicates that some larger particles seem to be present in the remaining solution, which have not settled after the $24 \mathrm{~h}$ period, indicating a good long term colloidal stability.

The saturation magnetization $\left(\mathrm{M}_{\mathrm{S}}\right)$ curves of $\mathrm{MP}_{\mathrm{ND}}$ and $\mathrm{rGO}$ hybrids were determined (Fig.

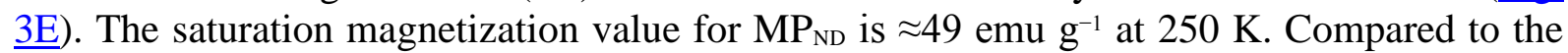
room temperature $\mathrm{M}_{\mathrm{S}}$ value of bulk $\mathrm{Fe}_{3} \mathrm{O}_{4}\left(\approx 92 \mathrm{emu} \mathrm{g^{-1 }}\right)$, the values of the $\mathrm{MP}_{\mathrm{ND}}$ particles are lower as expected, due to the mass of 2-nitrodopamine coating. ${ }^{28}$ The embedding of these nanostructures onto $\mathrm{rGO}$ results in a further decrease to $\approx 34 \mathrm{emu} \mathrm{\textrm {g } ^ { - 1 }}$ (Fig. 3E). Ferromagnetic behavior with a coercivity of about 280 Oe is observed for both nanostructures in accordance with XPS data showing the partial oxidation of the $\mathrm{MP}_{\mathrm{ND}}$ particles.

\subsection{Capture of bacterial cells}

To assess the enrichment effect of $\mathrm{rGO} / \mathrm{MP}_{\mathrm{ND}}$ particles under magnetic field separation, the $\mathrm{rGO} / \mathrm{MP}_{\mathrm{ND}}\left(500 \mu \mathrm{g} \mathrm{mL}^{-1}\right)$ was incubated for up to $30 \mathrm{~min}$ with E. coli and $\mathrm{S}$. aureus and then set on a magnet for magnetically driven sedimentation of the nanostructures with bound bacteria. As shown in Fig. 4A, $\mathrm{MP}_{\mathrm{ND}}$ particles show a removal capacity of $\sim 62 \%$ for E. coli and $\approx 32 \%$ for $\mathrm{S}$. aureus. The difference is believed to be due to the different charge states of Gram-positive and Gram-negative pathogens and that of the particles. ${ }^{8}$ At physiological $\mathrm{pH}$, $\mathrm{MP}_{\mathrm{ND}}$ particles exhibit a positive charge of $\sim 20 \pm 2 \mathrm{mV}$, favorable for E. coli separation with a negative charge at $\mathrm{pH} 7$ (Fig. 4B). Indeed, these findings were validated by using chitosan coated magnetic particles, $\mathrm{MP}_{\mathrm{CS}}$ (see the ESI, $\$$ Fig. S1A and B). These particles are negatively charged at physiological $\mathrm{pH}$ with a $\mathrm{pK}_{\mathrm{a}}$ of the $\mathrm{MP}_{\mathrm{CS}}$ nanostructures of $\sim 6.5$ and a positive zeta potential only recorded under acidic conditions. The capture efficiency for $\mathrm{E}$. coli was strongly decreased on these nanostructures (Fig. S1C, ESI $\perp$ ) and almost absent for S. aureus. This underlines that a positive surface potential is helpful for increasing the removal efficiency of pathogens, showing a negative surface potential under physiological conditions. 11

DOI: $10.1039 / \mathrm{C} 7 \mathrm{~TB} 01890 \mathrm{H}$ - Journal: Journal of Materials Chemistry B : Materials for biology and medicine - Post-print 
However, once attached to $\mathrm{rGO}$, the importance of the surface charge of the nanocomposite is masked by the strong interaction of E. coli and S. aureus with the underlying rGO nanosheets resulting in $100 \%$ capture efficiencies for Gram-positive and Gram-negative bacteria (Fig. $\underline{4 \mathrm{~A}})$.

(A)

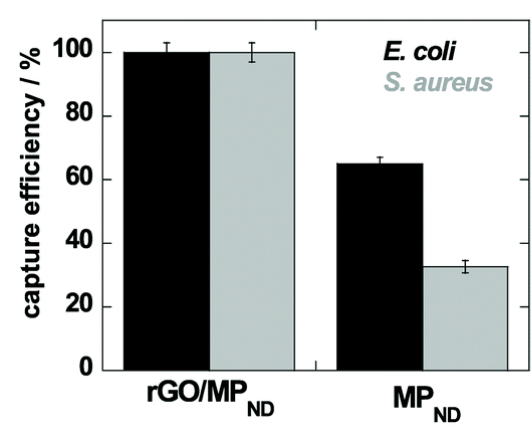

(B)

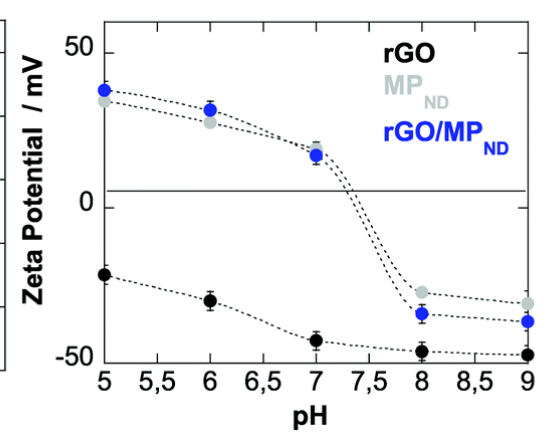

(C)

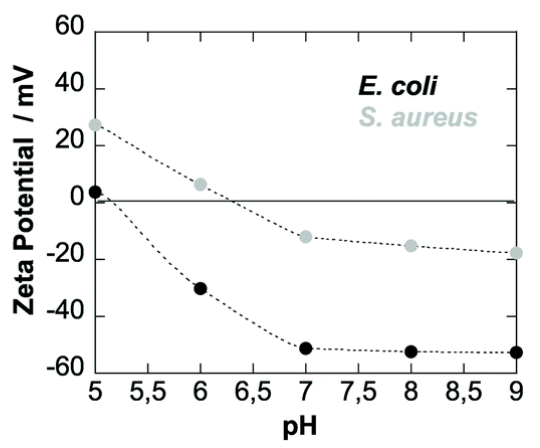

Fig. 4 (A) Removal efficiency of $\mathrm{MP}_{\mathrm{ND}}$ and $\mathrm{rGO} / \mathrm{MP}_{\mathrm{ND}}\left(500 \mu \mathrm{g} \mathrm{mL} \mathrm{mL}^{-1}\right)$ of E. coli and S. aureus $\left(1 \times 10^{9} \mathrm{cfu} \mathrm{mL} \mathrm{mL}^{-1}\right)$; (B) zeta potential of $\mathrm{rGO}, \mathrm{MP}_{\mathrm{ND}}$, and $\mathrm{rGO} / \mathrm{MP}_{\mathrm{ND}}$ as a function of solution $\mathrm{pH}$; (C) zeta potential of E. coli and S. aureus suspensions $\left(1 \times 10^{9} \mathrm{cfu} \mathrm{mL}^{-1}\right)$.

The time and concentration dependent capture efficiency of $\mathrm{rGO} / \mathrm{MP}_{\mathrm{ND}}$ are seen in Fig. $5 \mathrm{~B}$, showing a nonlinear concentration dependence with complete bacterial removal only reached at higher concentrations. Using $500 \mu \mathrm{g} \mathrm{mL}^{-1}$ of $\mathrm{rGO} / \mathrm{MP}_{\mathrm{ND}}$ resulted in complete bacterial removal in less than $30 \mathrm{~min}$ (Fig. 5A). From the SEM image in Fig. 5C, it can be seen that the bacteria are bound to the $\mathrm{rGO} / \mathrm{MP}_{\mathrm{ND}}$ and are partly embedded in the 3-D nanostructure.

(A)

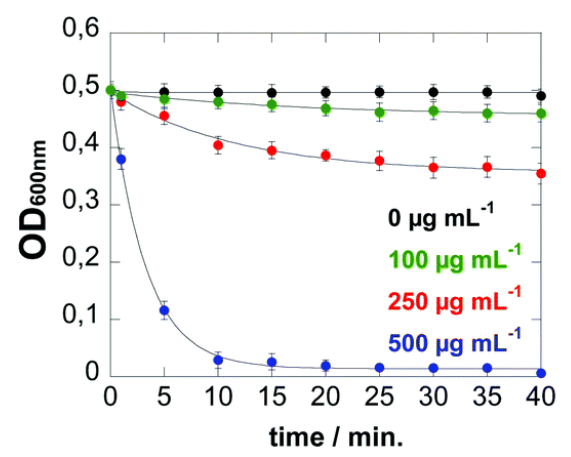

(C)

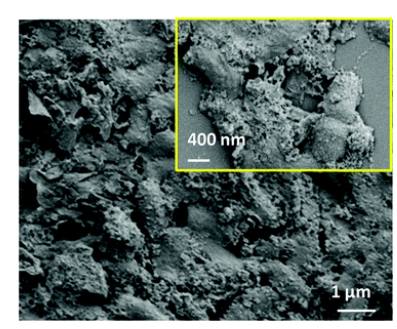

(B)

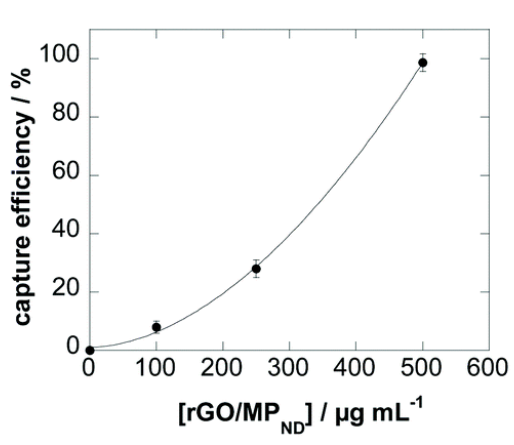

(D)

(E)

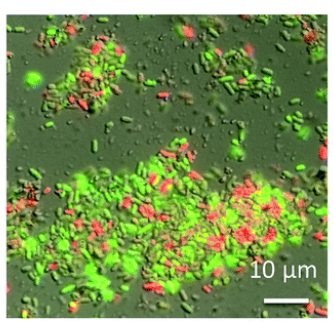

DOI: $10.1039 / \mathrm{C} 7 \mathrm{~TB} 01890 \mathrm{H}$ - Journal: Journal of Materials Chemistry B : Materials for biology and medicine - Post-print 
Fig. 5 (A) Change in $\mathrm{OD}_{600}$ over time as a function of the concentration of $\mathrm{rGO} / \mathrm{MP}_{\mathrm{ND}}$ upon incubation in E. coli UTI89 $\left(1 \times 10^{9} \mathrm{cfu} \mathrm{mL}^{-1}\right)$; (B) capture efficiency as a function of the concentration of $\mathrm{rGO} / \mathrm{MP}_{\mathrm{ND}}$; (C) SEM images of $\mathrm{rGO} / \mathrm{MP}_{\mathrm{ND}}$ mediated bacterial isolation; (D) confocal fluorescence images of live and dead bacterial cells after incubation of $500 \mu \mathrm{g} \mathrm{mL}^{-1}$ $\mathrm{rGO} / \mathrm{MP}_{\mathrm{ND}}$ for $30 \mathrm{~min}$ with E. coli UTI89 $\left(1 \times 10^{9} \mathrm{cfu} \mathrm{mL}^{-1}\right)$ and subsequent staining with SYTOP 9 (green, alive) and PI (red, dead); (E) photothermal heating curve of $\mathrm{rGO} / \mathrm{MP}_{\mathrm{ND}}(500$ $\left.\mu \mathrm{g} \mathrm{mL}^{-1}\right)$ under NIR illumination at $1 \mathrm{~W} \mathrm{~cm}^{-2}$ in distilled water $(1 \mathrm{~mL})$.

Graphene based matrices are reported for their strong antibacterial properties. ${ }^{29} \mathrm{~A}$ fluorescence-based cell live/dead assay was used to investigate the removal mechanism at hand. Fig. 5C shows an overlap of the fluorescence images after staining with SYTO9 and propodium iodide (PI). SYTO9 is a dye which enters through the bacterial membrane and colors in green both living and dead bacteria, while PI staining indicates dead bacteria due to damaged cell wall membranes and gives a red fluorescent color. A significant amount of green-stained cells is observed, and bacteria eliminated by $\mathrm{rGO} / \mathrm{MP} \mathrm{ND}_{\mathrm{ND}}$ are partially viable. To ablate totally the captured pathogens, the photothermal properties of $\mathrm{rGO} / \mathrm{MP} \mathrm{ND}_{\mathrm{ND}}$ in the nearinfrared (NIR) were examined. NIR photo-thermal treatment (PTT) is known for its deep penetration into tissue and in combination with rGO nanosheets is suitable for photo thermal ablation of pathogens. ${ }^{1,5,29-32}$ The effective light-to-heat conversion capability of rGO causes irreversible damage to bacterial cells and thus represents an efficient antibacterial treatment approach. Irradiation of $\mathrm{rGO} / \mathrm{MP}_{\mathrm{ND}}$ with a continuous laser at $980 \mathrm{~nm}$ for several minutes at a laser power of $1 \mathrm{~W} \mathrm{~cm}^{-2}$ results in a temperature increase for distilled water from $20 \pm 2{ }^{\circ} \mathrm{C}$ to $75 \pm 2{ }^{\circ} \mathrm{C}$ due to the photothermal heating effect (Fig. 5D). Irradiation of the bacteria loaded $\mathrm{rGO} / \mathrm{MP}_{\mathrm{ND}}$ matrix for 10 min resulted thus in total ablation of all the bacterial cells.

\subsection{Isolation efficiency for pathogen concentrations $<1 \times 10^{4} \mathrm{cfu} \mathrm{mL}^{-1}$}

Next to the quantitative evaluation of the nanocarrier's isolation efficiency of highly concentrated pathogens solutions, analysis of the capture capabilities of bacterial suspensions ranging from $1 \times 10^{1}$ to $1 \times 10^{4} \mathrm{cfu} \mathrm{mL}^{-1}$ is of utmost importance as the infectious doses of highly virulent pathogens are often $<1 \times 10^{1} \mathrm{cfu} \mathrm{mL}^{-1}$. The classical plate counting method was employed here to validate the removal capacity. The photos of plate counting for E. coli and S. aureus are depicted in Fig. 6. The counted colony number of the original bacterial solution (control) is significantly different from the counted colony numbers of the solution after incubation for $30 \mathrm{~min}$ with $\mathrm{rGO}-\mathrm{MP}_{\mathrm{ND}}\left(500 \mu \mathrm{g} \mathrm{mL}^{-1}\right)$ and magnetic separation. The capture efficiency of $\mathrm{rGO}-\mathrm{MP}_{\mathrm{ND}}$ remains excellent even at ultralow bacterial concentrations for E. coli and S. aureus alike.

DOI: $10.1039 / \mathrm{C} 7 \mathrm{~TB} 01890 \mathrm{H}$ - Journal: Journal of Materials Chemistry B : Materials for biology and medicine - Post-print 
E. Coli

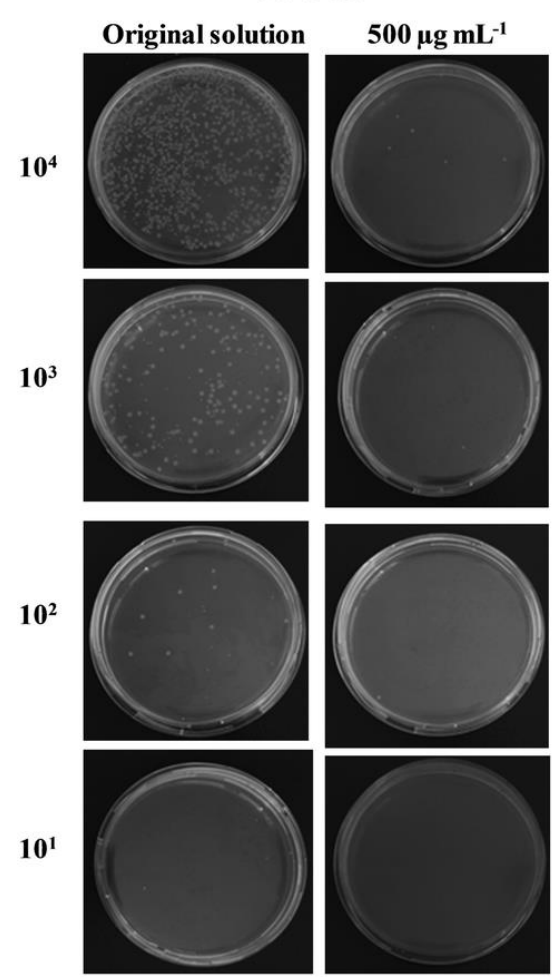

S. aureus

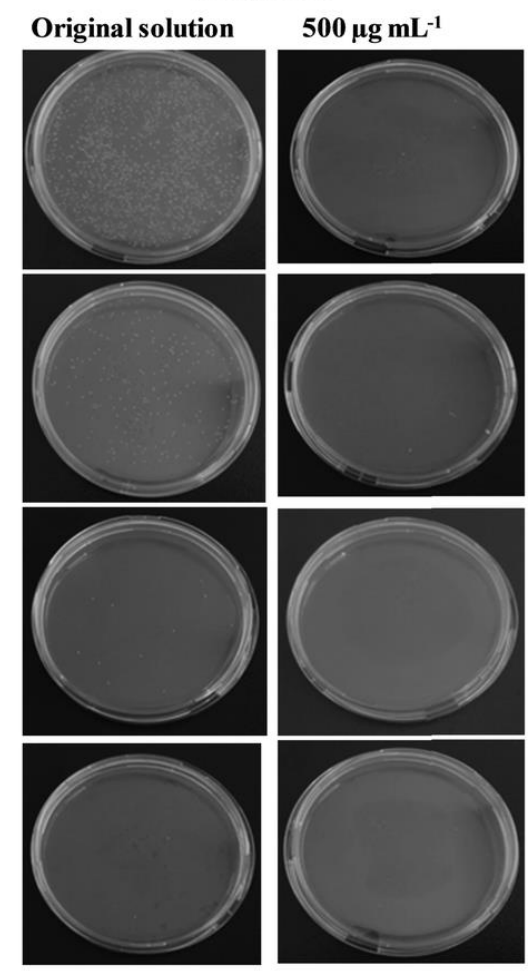

Fig. 6 Capture and separation efficiency of $\mathrm{rGO} / \mathrm{MP}_{\mathrm{ND}}$ for E. coli. Photos of plate cultures before and after treatment with $\mathrm{rGO} / \mathrm{MP}_{\mathrm{ND}}\left(500 \mu \mathrm{g} \mathrm{mL}^{-1}\right)$ for $30 \mathrm{~min}$.

\subsection{Specific removal of pathogenic E. coli UTI89}

When it comes to infectious diseases, the selective removal of pathogenic species in complex media such as human serum is important. This issue can only be accomplished by adding pathogen specific targeting sites onto $\mathrm{rGO} / \mathrm{MP}_{\mathrm{ND}}$. For some time our group has been interested in the development of inhibitors $\frac{33,34}{}$ and treatments $\frac{35}{5}$ for virulent strains of E. coli associated with urinary tract infections (UTIs). Among the targets that have been identified for the development of anti-adhesive strategies are type 1 fimbriae, which constitute major virulence factors produced by E. coli. $\frac{36}{}$ Type 1 fimbriae are filamentous proteinaceous organelles that are distributed over the entire surface of the bacterium. To achieve selective bacteria elimination, antibodies against the major pilin protein FimA of the E. coli UTI89 type-1 fimbriae were covalently anchored to $\mathrm{rGO} / \mathrm{MP}_{\mathrm{ND}}$ (Fig. 1) using the free $-\mathrm{NH}_{2}$ groups of the 2nitrodopamine coating of the magnetic particles. To avoid non-specific interaction with bacteria, the modified nanostructures were immersed into a solution of pyrene-PEG (Fig. 1), rendering the matrix anti-fouling. We used an azide modified pyrene-PEG as it allowed us to validate its integration using XPS (Fig. 7A). The high-resolution $\mathrm{N}_{1 \mathrm{~s}}$ XPS spectrum of the $\mathrm{rGO} / \mathrm{MP}_{\mathrm{ND}}$ nanostructure modified with pyrene-PEG-N $\mathrm{N}_{3}$ and anti-fimbrial antibodies reveals the azido function incorporation by the presence of signals at $405.2\left(\mathrm{Ar}-\mathrm{N}=\mathrm{N}^{+}=\mathrm{N}^{-}\right)$as reported for other $\mathrm{N}_{3}$-modified interfaces, $\underline{37}$ with the band at $401.9 \mathrm{eV}$ assigned to $\mathrm{Ar}-$ $\mathrm{N}=\mathrm{N}^{+}=\mathrm{N}^{-}$and the $-\mathrm{NH}-\mathrm{C}=\mathrm{O}$ linkage of the pyrene-PEG and of the anti-fimbrial linkage. The band at $399 \mathrm{eV}$ is due to the presence of unreacted primary $\mathrm{NH}_{2}$ groups on the $\mathrm{MP}_{\mathrm{ND}}$ particles and of the anti-fimbrial antibodies.

DOI: $10.1039 / \mathrm{C} 7 \mathrm{~TB} 01890 \mathrm{H}$ - Journal: Journal of Materials Chemistry B : Materials for biology and medicine - Post-print 
(A)

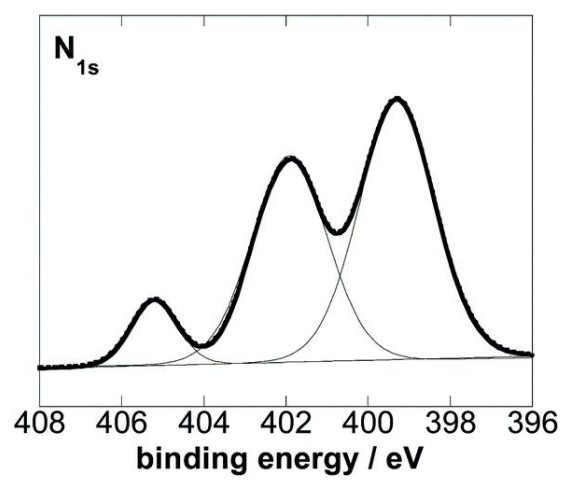

(C)
(B)

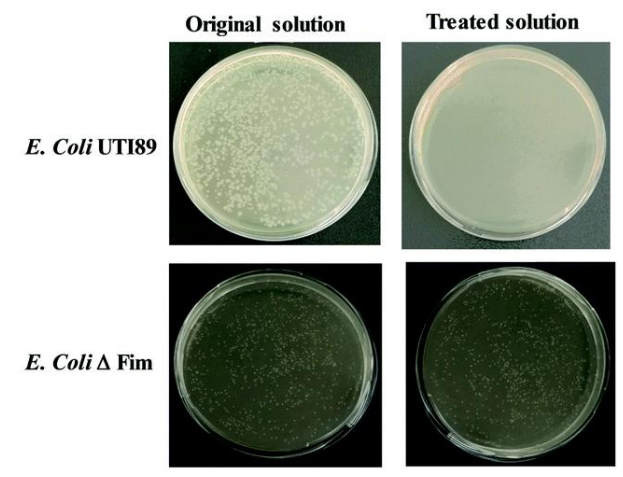

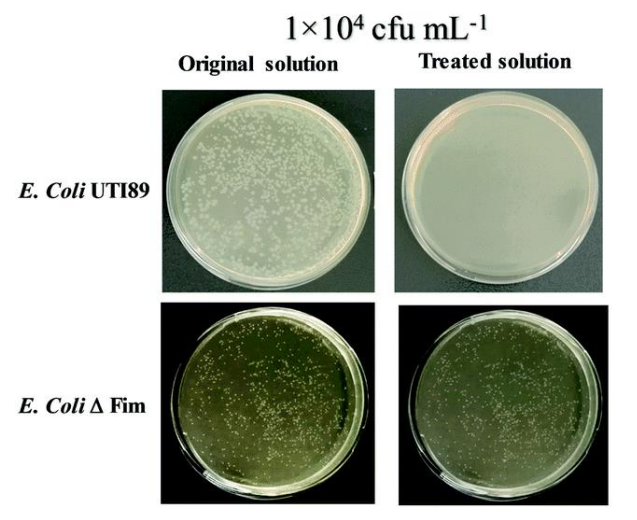

$1 \times 10^{2} \mathrm{cfu} \mathrm{mL}^{-1}$

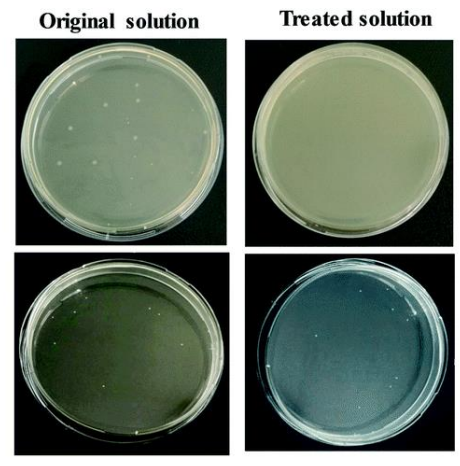

Fig. 7 (A) $\mathrm{N}_{\mathrm{ss}}$ high resolution XPS core level spectrum of azide terminated pyrene-PEG and anti-fimbrial modified $\mathrm{rGO} / \mathrm{MP}_{\mathrm{ND}}$; $(\mathrm{B})$ photos of plate cultures of the original solution of $\mathrm{E}$. coli UTI89 and E. coli $\Delta$ fim at $1 \times 10^{4} \mathrm{cfu}^{\mathrm{mL}^{-1}}$ after treatment with $\mathrm{rGO} / \mathrm{MP}_{\mathrm{ND}}(500 \mu \mathrm{g}$ $\mathrm{mL}^{-1}$ ) for $30 \mathrm{~min}$, (C) specific isolation of E. coli UTI89 over E. coli $\Delta$ fim from human

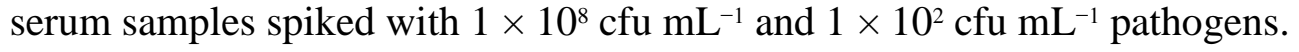

The capability of these nanostructures for the selective capturing of E. coli UTI89 was investigated further. As seen from the photos of plate counting assays (Fig. 7B) for wild type E. coli UTI89 and an E. coli UTI89 strain lacking type-1 fimbriae (UTI89 $\Delta$ fim), the complete removal of E. coli UTI89 is achieved, while none of the non-fimbriated E. coli were eliminated magnetically by the matrix.

The excellent results prompted us to investigate $\mathrm{rGO} / \mathrm{MP}_{\mathrm{ND}}$ nanocarriers for the removal of bacteria from contaminated serum samples. For this, serum samples spiked with $1 \times 10^{4} \mathrm{cfu}$ $\mathrm{mL}^{-1}$ or $1 \times 10^{2} \mathrm{cfu} \mathrm{mL}^{-1}$ E. coli UTI89 or E. coli $\Delta$ fim were exposed to rGO-MP $\mathrm{MD}_{\mathrm{ND}}(500 \mu \mathrm{g}$ $\mathrm{mL}^{-1}$ ) for $30 \mathrm{~min}$ before being magnetically separated. As seen in Fig. 7C, excellent capture efficiency could be achieved even in serum indicating an excellent enrichment capability of pyrene-PEG and anti-fimbrial modified $\mathrm{rGO} / \mathrm{MP}_{\mathrm{ND}}$ even in serum.

DOI: $10.1039 / \mathrm{C} 7 \mathrm{~TB} 01890 \mathrm{H}$ - Journal: Journal of Materials Chemistry B : Materials for biology and medicine - Post-print 


\section{Conclusions}

In summary, this study demonstrates the theranostic potential of anti-fimbrial modified magnetic rGO nanocomposites for a magnetic-separation based body fluid purification approach of E. coli UTI89. Owing to the large surface area of rGO and the magnetic properties of the integrated 2-nitrodopamine modified magnetic particles, the nanocomposite can rapidly capture bacteria, which can then be separated by an external magnetic field. Integration of E. coli UTI89 specific anti-fimbrial antibodies as well as anti-fouling pyrenePEG enabled the selective capturing of uropathogenic E. coli at low and high concentration levels. Furthermore, photothermal treatment of the E. coli captured nanocomposite results in a complete ablation of the eliminated pathogens. While the azido groups of the pyrene-PEG in this work have only been used as an XPS marker, in the future different "clickable" functional ligands can be easily integrated onto these magnetic nanocomposites which will open up further means of bacterial strain differentiation and will allow the addition of further antibacterial properties onto the matrix. We thus believe that this novel multi-functional pathogen capturing matrix provides an attractive avenue for pathogen decontamination and other biomedical purposes due to high efficiency even in complex media such as serum. While the therapeutic efficiency of E. coli UTI89 removal remains to be demonstrated in the clinic, the proposed approach is expected to help rapid cleaning of bodily fluids in a fast and selective manner.

\section{Conflicts of interest}

There are no conflicts to declare.

\section{Acknowledgements}

Financial support from the Centre National de la Recherche Scientifique (CNRS), the University of Lille, the Hauts-de-France region, the CPER "Photonics for Society", the Agence Nationale de la Recherche (ANR) and the EU union through FLAG-ERA JTC 2015Graphtivity, and the Marie Sklodowska-Curie action (H2020-MSCA-RISE-2015, PANG690836) are acknowledged. We kindly thank Dr Corentin Spriet, Bio Imaging Center Lille and Dr David Fournier, UMET, for providing the technical environment to perform the confocal and fluorescence measurements, respectively. L. C. thanks the Chinese government for the China Scholarship Council (CSC). We thank the CCM-RMN of Université Lille 1 (Marc Bria and Bertrand Doumert, C4) for NMR analyses. The Fonds Européen de Développement Régional (FEDER), CNRS, Région Nord Pas-de-Calais and Ministère de l'Education Nationale de l'Enseignement Supérieur et de la Recherche are acknowledged for funding of XPS/LEIS/ToF-SIMS spectrometers within the Pôle Régional d'Analyses de Surface.

DOI: $10.1039 / \mathrm{C} 7 \mathrm{~TB} 01890 \mathrm{H}$ - Journal: Journal of Materials Chemistry B : Materials for biology and medicine - Post-print 


\section{References}

1. F. I. Hai, T. Riley, S. Shawkat, S. F. Magram and K. Yamamoto, Water, 2014, 6, 3603-3630.

2. Y. L. F. Musico, C. M. Santos, M. L. P. Dalida and D. F. Rodrigues, ACS Sustainable Chem. Eng., 2014, 2, 1559-1565.

3. M. Zhu, W. Liu, H. Liu, Y. Liao, J. Wei, X. Zhou and D. Xing, ACS Appl. Mater. Interfaces, 2015, 7, 12873.

4. M. Behra, N. Azzouz, S. Schmidt, D. V. Volodkin, S. Mosca, M. Chanana, P. H. Seeberg and L. Hartmann, Biomacromolecules, 2013, 14, 1927-1935.

5. X. Jia, I. Ahmad, R. Yang and C. Wang, J. Mater. Chem. B, 2017, 5, 2459-2467.

6. T.-Y. Liu, C.-L. Chen, Y.-C. Lee, T.-Y. Chan, Y.-L. Wang and J.-J. Lin, ACS Appl. Mater. Interfaces, 2016, 8, 411-418.

7. B. M. Geilich, I. Gelfat, S. Sridhar, A. L. van de Ven and T. J. Webster, Biomaterials, 2017, 119, 78-85.

8. S. Zhan, D. Zhu, S. Ma, W. Yu, Y. N. Jia, Y. Li, H. Yu and Z. Shen, ACS Appl. Mater. Interfaces, 2015, 7, 4290-4298.

9. W. Fang, C. Han, H. Zhang, W. Wei, R. Liu and Y. Shen, RSC Adv., 2016, 6, 6787567882.

10. Y.-F. Huang, Y.-F. Wang and X.-P. Yan, Environ. Sci. Technol., 2010, 44, 79087913.

11. A. J. Kell, G. Steward, S. Ryan, R. Peytavi, M. Boissont, A. Huletsky, M. G. Bergeron and B. Simard, ACS Nano, 2008, 2, 1777-1788.

12. K. El-Boubbou, C. Gruden and X. Huang, J. Am. Chem. Soc., 2007, 129, 13392.

13. D.-T. Vo, C. G. Whitekley and C.-K. Lee, Ind. Eng. Chem. Res., 2015, 54, 92709277.

14. H. Gu, P.-L. Ho, K. W. T. Tsang, L. Wang and W. Xu, J. Am. Chem. Soc., 2003, 125, 15702.

15. G. B. Dadabdhara, P. K. Boruah, N. Hussain, P. Borthakur, B. Sharma, P. Sengupta and M. R. Das, Colloids Surf., A, 2017, 516, 161-170.

16. K. Cihalova, D. Hegerova, S. Dostalova, P. Jelinkova, L. Krejcova, V. Milosavljevic, S. Krizkova, P. Kopel and V. Adam, Anal. Methods, 2016, 8, 5123-5128.

17. M. Rodenstein, S. Zürcher, S. G. Tosatti and N. D. Spencer, Langmuir, 2010, 26, 16211.

18. A. Barras, S. Szunerits, L. Marcon, N. Monfilliette-Dupont and R. Boukherroub, Langmuir, 2010, 236, 13168.

19. M. Mazur, A. Barras, V. Kuncser, A. Galatanu, V. Zaitzev, K. V. Turcheniuk, P. Woisel, D. Lyskawa, W. Laure, A. Siriwardena, R. Boukherroub and S. Szunerits, Nanoscale, 2013, 5, 2692-2702.

20. E. Kaiser, R. L. Colescott, C. D. Bossinger and P. I. Cook, Anal. Biochem., 1970, 34, 595-598.

21. E. Amstad, A. U. Gehring, H. Fisher, V. V. Nagaiyanallur, G. Hähner, M. Textor and E. Reimhult, J. Phys. Chem. C, 2011, 115, 683.

22. E. Amstad, T. Gillich, I. Bilecka, M. Textor and E. Reimhult, Nano Lett., 2009, 9, 4042.

23. E. Amstad, M. Textora and E. Reimhult, Nanoscale, 2011, 3, 2819.

24. S. J. Clarke, C. A. Hollmann, Z. Zhang, S. Suffern, S. E. Bradforth, N. M. Dimitrijevic, W. G. Minarik and J. L. Nadeau, Nat. Mater., 2006, 5, 409.

DOI: $10.1039 / \mathrm{C} 7 \mathrm{~TB} 01890 \mathrm{H}$ - Journal: Journal of Materials Chemistry B : Materials for biology and medicine - Post-print 
25. G. Jarre, S. Heyer, E. Memmel, T. Meinhardt and A. Krueger, Beilstein J. Org. Chem., 2014, 10, 2729-2737.

26. R. A. Bini, R. F. C. Marques, F. J. Santos, J. A. Chaker and M. J. Jafelicci, J. Magn. Magn. Mater., 2012, 324, 534-539.

27. H. M. Cheng, G. M. Zhou, D. W. Wang, F. Li, L. L. Zhang, N. Li, Z. S. Wu, L. Wen and G. Q. Lu, Chem. Mater., 2010, 22, 5306-5313.

28. A. G. Roca, J. F. Marco, M. del Puerto Morales and C. J. Serna, J. Phys. Chem. C, 2007, 111, 18577-18584.

29. S. Szunerits and R. Boukherroub, J. Mater. Chem. B, 2016, 4, 6892-6912.

30. L. Xiao, J. Sun, L. Liu, R. Hu, H. Lu, C. Cheng, Y. Huang, S. Wang and J. Geng, ACS Appl. Mater. Interfaces, 2017, 9, 5382-5539.

31. B. Hu, N. Wang, L. Han, M.-L. Chen and J.-H. Wang, Chemistry, 2015, 21, 65826589.

32. M.-C. Wu, A. R. Deokar, J.-H. Liao, P.-Y. Shih and Y.-C. Ling, ACS Nano, 2013, 7, 1281-1290.

33. M. Khanal, F. Larsonneur, V. Raks, A. Barras, J.-S. Baumann, F. Ariel Martin, R. Boukherroub, J.-M. Ghigo, C. Ortiz Mettet, V. Zaitsev, J. M. Garcia Fernances, C. Beloin, A. Siriwardena and S. Szunerits, Nanoscale, 2015, 7, 2325-2335.

34. A. Barras, F. Ariel Martin, O. Bande, J.-S. Baumann, J.-M. Ghigo, R. Boukherroub, C. Beloin, A. Siriwardena and S. Szunerits, Nanoscale, 2013, 5, 2307.

35. K. Turcheniuk, C.-H. Hage, J. Spadavecchia, A. Yanguas Serrano, I. Larroulet, A. Pesquera, A. Zurutuza, M. Gonzalez Pisfil, L. Héliot, J. Boukaert, R. Boukherroub and S. Szunerits, J. Mater. Chem. B, 2015, 3, 375-386.

36. M. Hartmann and T. K. Lindhorst, Eur. J. Org. Chem., 2011, 3583-3609.

37. A. C. Gouget-Laemmel, J. Yang, M. A. Lodhi, A. Siriwardena, D. Aureau, R. Boukherroub, J.-N. Chazalviel, F. Ozanam and S. Szunerits, J. Phys. Chem. C, 2013, 117, 368-375

DOI: $10.1039 / \mathrm{C} 7 \mathrm{~TB} 01890 \mathrm{H}$ - Journal: Journal of Materials Chemistry B : Materials for biology and medicine - Post-print 